\title{
Studies on the Nature of the Killer Factor Produced by Saccharomyces cerevisiae
}

\author{
By D. R. WOODS* AND E. A. BEVAN \\ Botany School, Oxford, and Botany Department, \\ Queen Mary College, London, E.I \\ (Accepted for publication 20 September 1967)
}

\begin{abstract}
SUMMAR Y
Killer strains of yeast, Saccharomyces cerevisiae, liberate a killer factor into the medium which kills senstive yeast strains. The growth conditions necessary for the production of stable high-titre killer solutions and a biological assay for the killer factor are described. Purification was achieved by fractional precipitation with $\left(\mathrm{NH}_{4}\right)_{2} \mathrm{SO}_{4}$, dialysis, gel filtration and ultrafiltration. The fractionated killer factor is an unstable macromolecular protein which is inactivated by papain. The death of sensitive cells is not coincident with absorption of the killer factor, but can be delayed or prevented by variations in the environmental conditions. Sensitive cells are most susceptible to the action of the killer factor when in log phase. Treated resting cells on entering $\log$ phase are killed immediately.
\end{abstract}

\section{INTRODUCTION}

The killer reaction in yeast, Saccharomyces cerevisiae, was discovered by Bevan \& Makower (1963), who described how certain strains could be classified into one of three phenotypes which they termed 'killer', 'sensitive', and 'neutral'. When killer and sensitive cells are grown together in the same culture medium, a high proportion of the latter are killed. Neutral cells neither kill sensitive cells nor are they killed by killer cells. Killing can occur without cell contact between killer and sensitive cells. The agent released by the killer cells which causes the death of the sensitive cells has been called the 'killer factor'. Studies described here show it to be a proteinaceous substance with a highly specific action spectrum, dependent on specific $\mathrm{pH}$, temperature and aeration conditions.

The action of the killer factor resembles that of bacteriocins which do not cause lysis of the sensitive organisms and whose action is thus bactericidal, not bacteriolytic (Jacob \& Wollman, 1959).

\section{METHODS}

Strains. Three haploid strains of Saccharomyces cerevisiae possessing the same mating type $\alpha$, were used in the experiments: D I, a wild-type killer strain was used for the production of the killer factor; D 2, a wild-type sensitive strain for the sensitive control experiments; and D 3 , a marked $a d_{1}$ mutant sensitive strain which produces a red pigment (Reaume \& Tatum, 1949), as the sensitive strain in the tests performed to detect killing.

\footnotetext{
* Present address: Department of Microbiology, Rhodes University, Grahamstown, South Africa.
} 
Seeded agar phenotype test. The phenotypes of the strains were checked by replica plating (Lederberg \& Lederberg, 1952) colonies derived from single cells onto buffered complete agar medium containing $0.003 \%$ methylene blue and killer or sensitive cells ( $1 \mathrm{O}^{5}$ cells $/ \mathrm{ml}$.). Killer colonies were identified by zones of inhibition on the agar plates seeded with sensitive cells. Since methylene blue is a specific stain for dead yeast cells (Lindegren, 1949), the sensitive colonies were identified by a dark zone of dead cells on the agar plates seeded with killer cells. Neutral colonies showed no reaction on either killer or sensitive agar plates.

High-titre killer solutions. Stable high-titre killer solutions were obtained by incubating killer cells in buffered yeast complete or minimal medium (Bevan, 1955) at $22-24^{\circ}$ for 3 days. The liquid minimal medium was supplemented with $0.05 \%$ gelatine, and for agar media a $2 \%(\mathrm{w} / \mathrm{v})$ concentration of agar was utilized. All media were buffered at $\mathrm{pH} 4.8$ with a $0.077 \mathrm{M}$ citrate/phosphate buffer (Gomori, 1959). The solutions were sterilized by filtration through Oxoid membrane filters

Well test. The Wilkins technique (1949) for obtaining inhibition zones in seeded agar was used for the assay of the killer factor in liquid media. $0.05-0 . \mathrm{I} \mathrm{ml}$. aliquots of the solutions to be assayed were added to 4 holes $13 \mathrm{~mm}$. diam. in $10 \mathrm{ml}$. seeded agar plates ( $\mathrm{IO}^{3} a d_{1}$ sensitive cells $/ \mathrm{ml}$.). The plates were kept for 0-2 hr at room temperature before being incubated overnight at $28^{\circ}$.

Agar-layer technique. The technique of assaying for the killer factor in agar medium was evolved by Makower (1964). Plates spread with a lawn of wild-type killer or sensitive (control) cells were incubated for 5-7 hr at $28^{\circ}$ before a $10 \mathrm{ml}$. cooled agar layer was placed on top of the background cells. The plates were then incubated for 6-9 hr before spreading the marked ( $a d_{1}$ red) sensitive cells (I 50 cells/plate) on the surface. After a further $18 \mathrm{hr}$ incubation the plates were replicated onto fresh agar medium, and the \% of marked sensitive cells killed was obtained by comparing the number of red colonies arising on treated (killer background) and control (sensitive background) plates.

Purification. The killer factor was precipitated from minimal medium solutions supplemented with $0.05 \%(\mathrm{w} / \mathrm{v})$ gelatine by $30 \%\left(\mathrm{NH}_{4}\right)_{2} \mathrm{SO}_{4}$ saturation. The sediments were washed and resuspended in $0.077 \mathrm{M}$-citrate/phosphate buffer at $\mathrm{pH} 4.8$ before being dialysed against the buffer. The killer factor was further fractionated by gel filtration at $0-4^{\circ}$ with $\mathrm{I} \cdot 5 \times 30 \mathrm{~cm}$ Sephadex G-I 50 gel columns prepared by the method of Andrews (1965). The columns were equilibrated and eluted at a flow rate of $20 \mathrm{ml} . / \mathrm{hr}$ with $0.0853 \mathrm{M}$-citrate/phosphate buffer $\left(\mathrm{pH}_{4} \cdot 8\right)$ containing $0.008 \mathrm{M}-\mathrm{MgSO}_{4}: 2 \mathrm{ml}$. starting samples were applied to the columns, and the effluents collected in $5 \mathrm{ml}$. fractions. The effluent volume containing the purified killer factor was concentrated by the pressure dialysis method of Hofsten \& Falkbring (1960), using Visking tubing $8 / 32$ at $0-4^{\circ}$.

Examination of column effluents. The killer factor was assayed by the Well test; and the proteins and nucleic acids by light-extinction measurements at 280 and $260 \mathrm{~m} \mu$. Proteins were also measured by the colorimetric method of Lowry, Rosebrough, Farr \& Randall (I95I) as modified by Eggstein \& Kreutz (I955).

Sucrose density-gradient centrifugation. $0.5 \mathrm{ml}$. killer factor samples were layered on a $4-\mathrm{I} 8 \%$ sucrose gradient and the tubes centrifuged at $107,000 \mathrm{~g}$ for $6 \mathrm{hr}$ at $0-4{ }^{\circ}$ in an M.S.E. Super 40 swing-out rotor. The contents of the tubes were collected and assayed as 8-10 drop fractions after the bottoms of the tubes had been punctured. 
Agar-gel electrophoresis. The electrophoresis was carried out using microscope slides covered by a buffered homogeneous I \% (w/v) Oxoid Ionagar layer $2 \mathrm{~mm}$. in thickness, at a constant current" of $2 \mathrm{~mA}$ per inch width of agar and at a potential of $30 \mathrm{~V}$ for I 5-20 hr. After the electrophoresis the agar slides were cut in half longitudinally and each half was characterized for proteins and killer activity respectively. Proteins were stained by the nigrosin method of Weime (1965). The killer factor was identified by pipetting in a line down the centre of the agar strip, $0.075 \mathrm{ml}$. of a fourfold-strength buffered complete medium containing $0.06 \%$ methylene blue and $10^{4}$ sensitive cells $/ \mathrm{ml}$. After overnight incubation at $28^{\circ}$ the slides were examined for zones of inhibition.

Electron Microscopy. Serial dilutions of the fractionated killer factor were shadowed with chromium and then examined under a Siemens Elmiskop I A electron microscope.

\section{RESULTS}

Well-test assay technique. Although subject to the effect of well-known variables like duration of incubation (Kavanagh, 1963), type of medium or genotype of the seeded sensitive cells (Woods, I966), the Well test under standardized conditions was a reliable quantitative assay for the killer factor. The results in Fig. I show that at high concentrations of the killer factor there was a linear relationship between the square of the diameter of the inhibition zone and the log of the killer factor concentration.

\section{Effects of physical and chemical agents on the production and stability of the killer factor}

Effect of $\mathrm{pH}$. The optimum $\mathrm{pH}$ for the production and stability of the killer factor was determined by incubating killer cells at $22^{\circ}$ for 2 days in media buffered at different

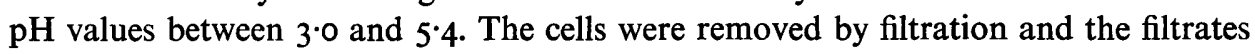
retained at $28^{\circ}, 22^{\circ}, \mathrm{I} 2^{\circ}$ and $4^{\circ}$ for $\mathrm{I} \mathrm{hr}$ and $24 \mathrm{hr}$, before the killer activity was estimated by the Well test.

The results shown in Table $\mathrm{I}$ indicate that the optimum $\mathrm{pH}$ for the production and stability of the killer factor in liquid medium lies within the narrow range $\mathrm{pH} 4 \cdot 6-4 \cdot 8$.

Effect of temperature. To determine the effect of temperature on the killer factor in liquid medium, aliquots of a killer solution were kept at $18^{\circ}, 23^{\circ}, 25^{\circ}, 28^{\circ}$ and $37^{\circ}$ respectively for different time intervals between 0 and $4 \mathrm{hr}$ before estimating the killer activity by the Well test.

The results expressed in Fig. 2 illustrate that in buffered liquid medium the killer factor was inactivated by temperatures above $25^{\circ}$. Such inactivation may be due to a protease derived from the yeast cells and the temperature effect may reflect the $Q_{10}$ for digestion.

In agar medium, on the other hand, the killer factor was markedly more stable and was only inactivated by temperatures above $42^{\circ}$ (Fig. 3 ). This was shown using the agar-layer technique and comparing the percentage killing on killer plates incubated at $28^{\circ}, 37^{\circ}, 42^{\circ}, 43^{\circ}, 44^{\circ}$ and $45^{\circ}$ respectively for $5 \mathrm{hr}$ after the addition of the top agar layers and also an initial incubation period for $7 \mathrm{hr}$ at $28^{\circ}$. Makower (1964) showed that the length of this initial period at $28^{\circ}$ between the addition of the top agar layers and the spreading of the sensitive cells greatly affected the percentage killing. Thus, a decrease in the percentage killing between the killer plates incubated throughout the experiment at $28^{\circ}$ and those incubated at different temperatures following the initial 


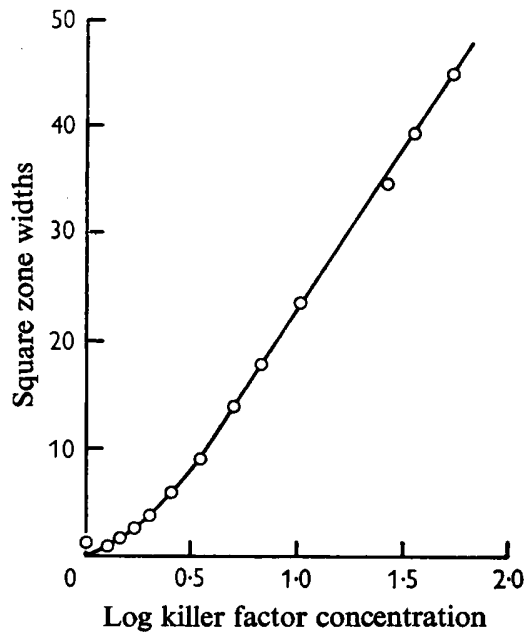

Fig. I

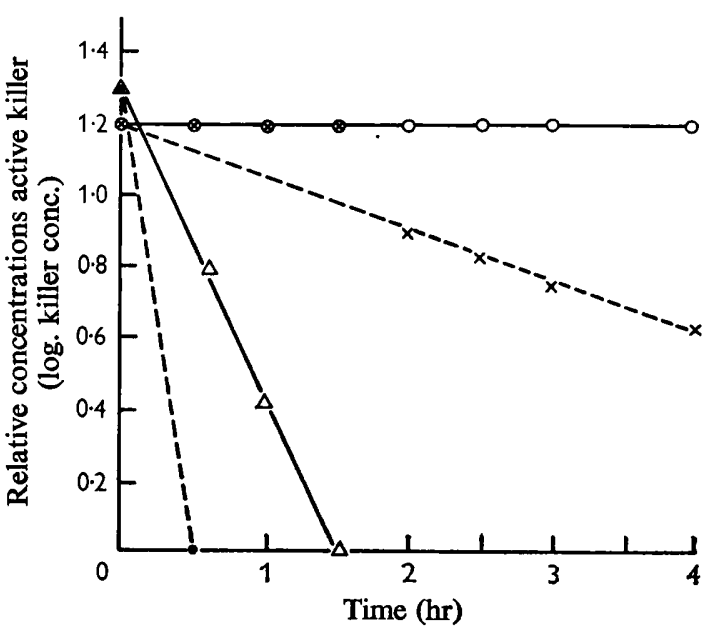

Fig. 2

Fig. I. Dilution of the killer factor: Well test.

Fig. 2. Effect of temperature on the killer factor in liquid complete medium. $O, 18^{\circ}$ and $23^{\circ} ; \times, 25^{\circ} ; \triangle, 28^{\circ} ; \bullet, 38^{\circ}$.

\section{Table 1. Effect of $p H$ on the stability of the killer factor}

Relative concentrations of active killer (log killer concentrations)

\begin{tabular}{|c|c|c|c|c|c|}
\hline $\begin{array}{l}\mathrm{pH} \text { of } \\
\text { medium }\end{array}$ & $\begin{array}{c}\text { o hr } \\
\text { (cultures } \\
\text { harvested) }\end{array}$ & $\begin{array}{c}\text { I hr } \\
28^{\circ}\end{array}$ & $\begin{array}{c}24 \mathrm{hr} \\
22^{\circ}\end{array}$ & $\begin{array}{c}24 \mathrm{hr} \\
12^{\circ}\end{array}$ & $\begin{array}{c}24 \mathrm{hr} \\
4^{\circ}\end{array}$ \\
\hline $5 \cdot 4$ & 0 & 0 & 0 & 0 & 0 \\
\hline $5 \cdot 2$ & 0 & 0 & 0 & 0 & 0 \\
\hline $5^{\circ} 0$ & 0.53 & 0 & 0.53 & 0.53 & 0.53 \\
\hline $4 \cdot 8$ & $I \cdot 40$ & 0.53 & $I \cdot 40$ & $I \cdot 40$ & $I \cdot 40$ \\
\hline $4 \cdot 6$ & $I \cdot 40$ & 0.53 & $I \cdot 40$ & $I \cdot 40$ & $I \cdot 40$ \\
\hline $4 \cdot 4$ & $I \cdot 40$ & 0 & 0.75 & $I \cdot 40$ & $I \cdot 40$ \\
\hline 40 & $I \cdot 40$ & 0 & 0 & $I \cdot 40$ & $I \cdot 40$ \\
\hline $3 \cdot 6$ & 0.53 & 0 & 0 & 0.10 & 0.53 \\
\hline $3 \cdot 4$ & 0.30 & 0 & 0 & 0 & 0.30 \\
\hline $3 \cdot 2$ & 0 & 0 & 0 & 0 & 0 \\
\hline 3.0 & 0 & 0 & 0 & 0 & 0 \\
\hline
\end{tabular}

incubation period, would indicate that the killer factor produced at $28^{\circ}$ was being inactivated.

It can be concluded from these experiments that the inactivation of the killer factor by temperature depends upon the composition of the medium.

Surface inactivation. It was observed that the killer activity of a minimal medium solution disappeared on sterilization by filtration. To determine whether or not the inactivation was due to surface inactivation caused by aeration, the effect of vigorously shaking aliquots of killer complete medium and minimal medium containing increasing quantities of gelatine for $0,2,4$ and $8 \mathrm{~min}$. at $22^{\circ}$ was studied.

It can be seen from Fig. 4 that the killer factor was rapidly inactivated when 
vigorously aerated and, like many physiologically active proteins and bacteriophages, this surface inactivation was prevented by gelatine (Adams, I948).

Effect of yeast extract. The results in Table 2 show that yeast extract enhanced the production of the factor by killer cells. A similar effect of yeast extract on the production of maltases by Saccharomyces oviformis was reported by Lewis (personal communication).

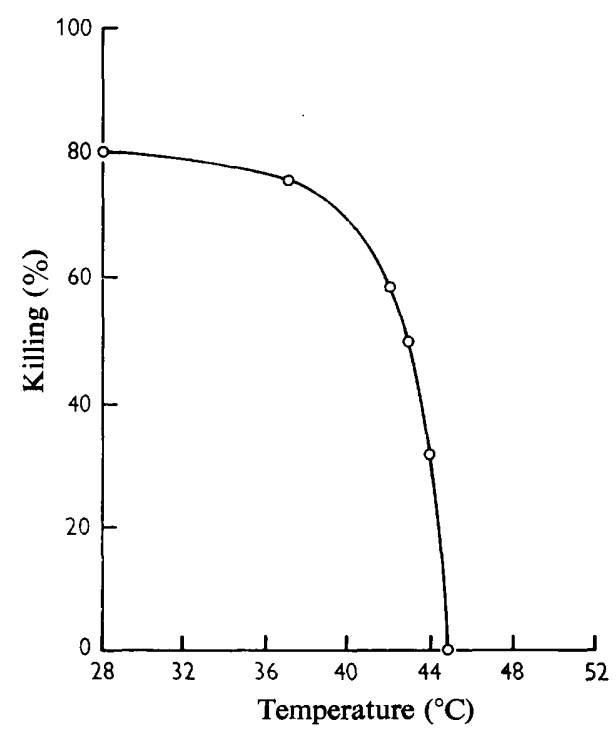

Fig. 3

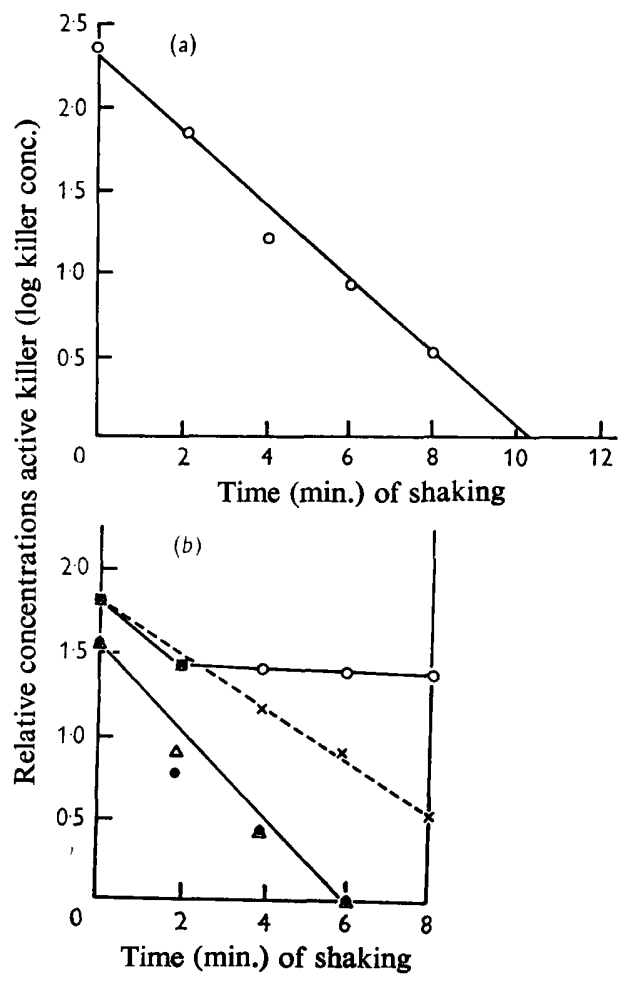

Fig. 4

Fig. 3. Effect of temperature on the killer factor in agar complete medium.

Fig. 4. Effect of vigorous aeration on the killer factor. (a) Inactivation of the killer factor in complete medium by shaking. (b) Inactivation of the killer factor in minimal medium by shaking in the presence of increasing quantities of gelatine. $0,0.25 \%(\mathrm{w} / \mathrm{v}) ; x, 0.05 \%(\mathrm{w} / \mathrm{v})$; $\triangle, 0.005 \%(w / v) ; \bullet, 0 \%(w / v)$ gelatine.

Table 2. Effect of various growth media on the production of the killer factor by killer cells

Type of killer medium

$\mathrm{CM}^{*}+$ gelatine

$\mathrm{MM} \dagger+$ gelatine + yeast extract

MM+ gelatine + peptone

$\mathrm{MM}+$ gelatine + casein hydrolysate

$\mathrm{MM}+$ gelatine
No. of yeast/ml. at harvesting

$14 \times 10^{7}$

$12 \times 10^{7}$

$14 \times 10^{7}$

$14.5 \times 10^{7}$

$10 \times 10^{7}$
Relative concentrations of active killer (log killer concentration)

$2 \cdot 3$
$2 \cdot 3$
$I \cdot 59$
$1 \cdot 40$
$I \cdot 05$

$\dagger$ Minimal medium. 


\section{PURIFICATION}

$\left(\mathrm{NH}_{4}\right)_{2} \mathrm{SO}_{4}$ fractionation. The results of the fractionation of the killer factor from chemically defined media, summarised in Table 3, indicate that it was precipitated by $70-81 \%$ saturation with $\left(\mathrm{NH}_{4}\right)_{2} \mathrm{SO}_{4}$ from complete and minimal media. However, when $0.05 \%(\mathrm{w} / \mathrm{v})$ gelatine was added to the minimal medium the factor was precipitated with the gelatine at $25-30 \%$ saturation with $\left(\mathrm{NH}_{4}\right)_{2} \mathrm{SO}_{4}$ and yielded a stable killer sediment with the highest specific activity. Agar-gel electrophoresis studies confirmed that only the killer factor and gelatine were precipitated (Fig. 6). The results

Table 3. Fractionation of the killer factor by $\left(\mathrm{NH}_{4}\right)_{2} \mathrm{SO}_{4}$ from complete and minimal media

$\begin{array}{lcccc}\text { Killer factor solution } & \begin{array}{c}\text { \% saturation } \\ \text { with }\left(\mathrm{NH}_{4}\right)_{2} \mathrm{SO}_{4} \\ \text { required to } \\ \text { precipitate } \\ \text { killer } \\ \text { factor }\end{array} & \begin{array}{c}\text { Complete } \\ \text { medium }\end{array} & \begin{array}{c}\text { Stability resuspended } \\ \text { sediment }\end{array} & \begin{array}{c}\text { Specific } \\ \text { activity } \\ \text { sediments } \\ \text { in buffer }\end{array} \\ \text { factor + complete medium } & 70-81 & + & + & \text { 100 } \\ \text { factor+minimal medium } & 70-81 & + & - & 0 \\ \text { factor + minimal medium }+ & 25-30 & + & + & 850\end{array}$

$$
+ \text {, Stable. } \quad-\text {, Unstable. }
$$

Table 4. Concentration by ultrafiltration of the purified-killer-factor peak and a sensitive control sample (effiuent volume 75-100 ml.) after gel filtration with Sephadex G-I 50

\begin{tabular}{|c|c|c|c|c|}
\hline \multirow[b]{2}{*}{ Samples } & \multirow{2}{*}{$\begin{array}{c}\text { Relative } \\
\text { concentrations } \\
\text { of active } \\
\text { killer }\end{array}$} & \multicolumn{2}{|c|}{ Absorption } & \multirow{2}{*}{$\begin{array}{l}\text { Folin test: } \\
\text { absorption } \\
\quad 750 \mu\end{array}$} \\
\hline & & $280 \mu$ & $260 \mu$ & \\
\hline Killer $a$ & 0.10 & 0.015 & 0.025 & $0.0 \mathrm{I}$ \\
\hline Killer $b$ & 0.53 & 0.155 & 0.1875 & 0.03 \\
\hline Killer $c$ & 0 & -0.005 & 0 & 0.0125 \\
\hline Sensitive $a$ & 0 & -0.02 & -0.03 & 0.0075 \\
\hline Sensitive $b$ & 0 & -0.015 & -0.02 & 0.0075 \\
\hline Sensitive $c$ & 0 & -0.025 & -0.0375 & 0.0075 \\
\hline
\end{tabular}

$a$, Effluent volume $75-100 \mathrm{ml}$. before concentration by ultrafiltration. $b$, Sample concentrated by ultrafiltration.

$c$, Buffer removed during ultrafiltration.

also show that the fractionated killer factor was not stable but could be stabilized by resuspension in a diluent containing gelatine or the other proteins present in complete medium.

Gel filtration. The gel-filtration elution profiles of the dialysed killer factor plus gelatine (Fig. 5) illustrated that the factor was eluted at two peaks: a sharp peak between 15 and $30 \mathrm{ml}$. effluent volume coinciding with the gelatine peak which was excluded by Sephadex G-I50 and was eluted at the void volume; and a second fractionated peak eluted between 70 and I $10 \mathrm{ml}$. The fractionated killer factor was unstable and became inactive after retention at $0-4^{\circ}$ for $34 \mathrm{hr}$. It can also be seen from Fig. 5 that there was no correlation between the second killer peak and the absorption at 260 and $280 \mathrm{~m} \mu$. The considerable degree of killer activity of this fraction as indi- 
cated by the Well test illustrated the high sensitivity of this biological assay as compared with the physical and chemical methods employed. It was found possible to estimate the killer factor, by physical and chemical tests, only after the fractionated factor had been concentrated by ultrafiltration (Table 4).

The elution of the killer factor in two peaks suggested that either there were two different factors, or polymers capable of causing the killer reaction. Alternatively the fractionation by gel filtration resulted in the separation of only some of the killer

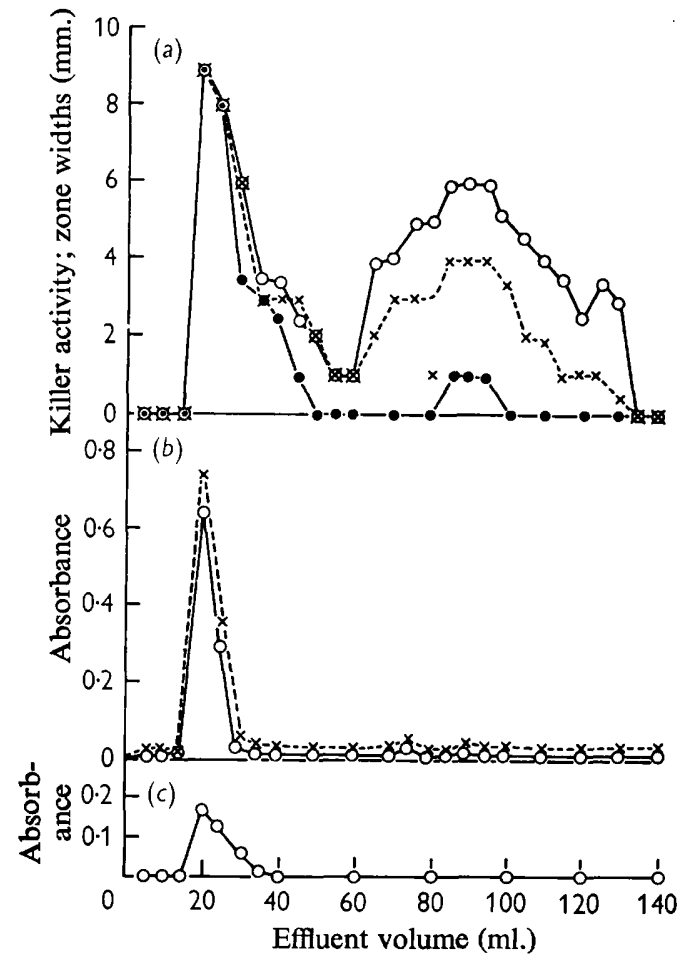

Fig. 5

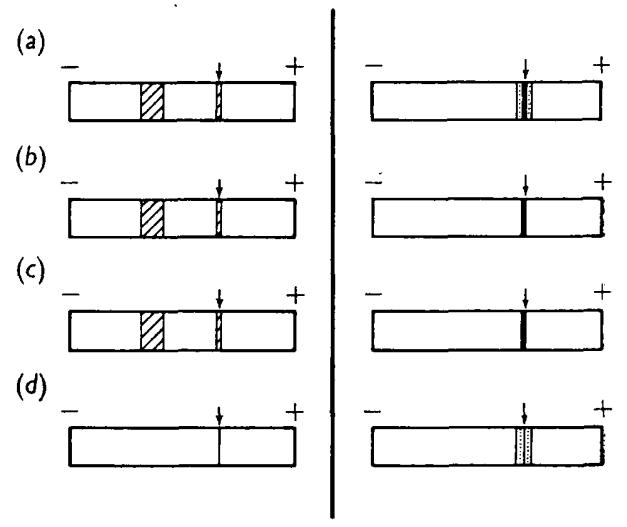

Fig. 6

Fig. 5. Elution profiles of the killer factor and gelatine sample after gel filtration with Sephadex G-I5O. (a) Killer activity at different time intervals between o and $34 \mathrm{hr}$. after gel filtration. $\mathrm{O}, \mathrm{o} \mathrm{hr} ; \times, \mathrm{I} 2 \mathrm{hr} ; 0,34 \mathrm{hr}$. (b) Absorption at ( $\times$ ) $260 \mathrm{~m} \mu$ and (O) $280 \mathrm{~m} \mu$. (c) Folin-Ciocalteu test for proteins (absorption at $750 \mathrm{~m} \mu$ ).

Fig. 6. Agar-gel electrophoresis. (a) Killer factor+gelatine sample after $30 \%\left(\mathrm{NH}_{4}\right)_{2} \mathrm{SO}_{4}$ fractionation. (b) Sensitive control solution + gelatine sample after $30 \%\left(\mathrm{NH}_{4}\right)_{2} \mathrm{SO}_{4}$ fractionation. (c) Gelatine sample. (d) Purified killer factor sample after concentration by ultrafiltration. $\downarrow$, origin, $\square$, protein stain (gelatine); $\mathbf{\square}$, purple stain (gelatine at origin + methylene blue); 国, zone of inhibition (killer factor).

factor from the gelatine. To distinguish between these possibilities an attempt was made to separate the killer factor and gelatine by sucrose density-gradient centrifugation prior to gel filtration. Although the killer factor was dispersed throughout the gradient (Woods, 1966), it was possible to separate the bulk of it from the gelatine, since the latter was confined to a sharp peak at the top of the gradient.

After gel filtration this gelatine-free factor was eluted between 65 and $100 \mathrm{ml}$. effluent volume only. It was therefore concluded that the killer factor eluted at the 
void volume was attached to the gelatine, and was thus not fractionated by gel filtration with Sephadex G-I50.

It is interesting to.note that the killer factor was hetero-dispersed after centrifugation in a sucrose gradient and also following ultracentrifugation in complete medium for $3 \mathrm{hr}$ at $107,000 \mathrm{~g}$.

The killer factor and gelatine sample eluted at the void volume were recycled but the killer factor was again only eluted at the void volume along with the gelatine. Recycling the fractionated killer factor failed to yield an effluent with any killer activity, presumably due to its instability in the absence of gelatine and to dilution effects.

In fractionations by gel filtration where the separation is governed entirely by the molecular-sieve effect, the distribution coefficient $(K d)$ cannot be greater than unity, and it is possible to estimate the molecular weights of proteins from the elution volume (Granath \& Flodin, 196I ; Andrews, 1965). However, the $K d$ for the separation of the killer factor was 2.59 . This indicates that adsorption was also taking place, and it was therefore impossible to estimate the molecular weight of the killer factor by this method.

Agar-gel electrophoresis. This technique was used to demonstrate the fractionation of the killer factor during the purification process. The pherograms of the experiments illustrated in Fig. 6 show that the killer factor remained at the origin and was not affected by electrophoresis at $\mathrm{pH} 4 \cdot 6$. The purified killer sample, which contained no detectable contaminant proteins, was only identifiable by a zone of inhibition at the origin. The dialysed killer sample, which had not been further purified, contained only the killer factor and gelatine (Fig. 6).

Electrophoresis was carried out at different $\mathrm{pH}$ values between $\mathrm{pH} 4.0$ and 5.0 and several conclusions can be made from the results. First, the killer factor was only identifiable by zones of inhibition at the origin between $\mathrm{pH} 4.6$ and 4.8 ; this was expected as it is unstable at other $\mathrm{pH}$ values. Secondly, there was no other migrating protein band at any of the $\mathrm{pH}$ values besides that formed by gelatine.

Degree of purification. The results given in Table 4 show that a 40 -fold purification of the killer factor was achieved by the procedures described. It should be pointed out, however, that this estimate is a conservative one due to the fact that the killer factor was gradually inactivated once it had separated from the stabilizing gelatine. Thus a certain amount of inactivation always occurred before the assay procedure could be performed.

Electron microscopy. Serial dilutions of the purified killer factor were examined under the electron microscope but it was not detected by the technique adopted.

Effect of papain. Evidence for the proteinaceous nature of the killer factor was obtained by the study of the effect of the plant protease enzyme, papain, which has a maximum enzymic activity between pH 5 and 7.5 (Kimmel \& Smith, 1954):0.2 ml. aliquots of a minimal-medium killer solution and a purified-killer-factor solution were added to $0.2 \mathrm{ml}$. aliquots of an activated papain (crystalline B.D.H.) solution containing $0.025 \mathrm{M}$-cysteine and $0.005 \mathrm{M}$-versene; an inactive papain solution (papain alone); and a solution containing cysteine and versene. The solutions were incubated at $20^{\circ}$ and the killer activity determined after $0,4,6$ and $20 \mathrm{hr}$.

The results shown in Table 5 indicate that only the killer factor was inactivated by papain. Since it was inactivated by papain only in the presence of the reducing agents it is concluded that the proteolytic action of the enzyme was responsible. The eventual 
loss of killer activity by the purified killer control sample was due to the unstable nature of the fractionated killer factor.

Mode of action of the killer factor. The susceptibility of the sensitive cells was studied by comparing the $\%$ killing at different stages in the growth cycle. The sensitive cells were most susceptible during active growth but were completely resistant during stationary phase (Woods, I966). Similar effects associated with changes in growth rate are well known in bacteria (Topley \& Wilsons Principles 1964).

Table 5. Effect of the protease enzyme, papain, on the killer factor

\begin{tabular}{|c|c|c|c|}
\hline \multirow[b]{2}{*}{ Sample } & \multicolumn{3}{|c|}{$\begin{array}{c}\text { Relative concentrations } \\
\text { of active killer } \\
\text { (log killer concentration) }\end{array}$} \\
\hline & o hr & $6 \mathrm{hr}$ & $20 \mathrm{hr}$ \\
\hline Killer factor + $\mathbf{M M}^{*}+$ gelatine & $1 \cdot 40$ & $1 \cdot 40$ & $I \cdot 40$ \\
\hline $\begin{array}{l}\text { Killer factor }+\mathrm{MM}+\text { gelatine }+ \text { cysteine }+ \\
\text { versene }\end{array}$ & $I \cdot 40$ & $1 \cdot 40$ & $1 \cdot 05$ \\
\hline Killer factor + MM + gelatine + papain & $I \cdot 40$ & $1 \cdot 40$ & $I \cdot 40$ \\
\hline $\begin{array}{l}\text { Killer factor + MM + gelatine + cysteine + } \\
\text { versene + papain }\end{array}$ & $1 \cdot 40$ & 0.30 & 0 \\
\hline Purified killer factor & 0.53 & 0.30 & 0 \\
\hline Purified killer factor + papain & 0.53 & 0.30 & 0 \\
\hline $\begin{array}{l}\text { Purified killer factor }+ \text { cysteine }+ \\
\text { versene + papain }\end{array}$ & 0.53 & 0 & 0 \\
\hline
\end{tabular}

Table 6. Effect of temperature and $\mathrm{pH}$ on the post-absorption action of the killer factor

\begin{tabular}{|c|c|c|c|c|}
\hline \multirow[b]{2}{*}{ Exp. } & \multirow[b]{2}{*}{ Type of medium } & \multicolumn{2}{|c|}{$\begin{array}{l}\text { Post-absorption } \\
\text { treatment }\end{array}$} & \multirow[b]{2}{*}{ (\%) Killing } \\
\hline & & $\mathrm{pH}$ & Temp. ${ }^{\circ}$ & \\
\hline \multirow[t]{8}{*}{ I } & Sensitive & $4 \cdot 8$ & 22 & o \\
\hline & & $5 \cdot 8$ & 38 & 0 \\
\hline & Killer & $4 \cdot 8$ & 22 & $57 \cdot 6$ \\
\hline & & $5 \cdot 8$ & 22 & $43 \cdot 0$ \\
\hline & & $4 \cdot 8$ & 28 & $5 I \cdot 2$ \\
\hline & & 5.8 & 28 & $3 I \cdot 0$ \\
\hline & & $4 \cdot 8$ & 38 & $25 \cdot 2$ \\
\hline & & $5 \cdot 8$ & 38 & $18 \cdot 7$ \\
\hline \multirow[t]{6}{*}{2} & Sensitive & $4 \cdot 8$ & 18 & 0 \\
\hline & & $4 \cdot 8$ & 38 & 0 \\
\hline & Killer & $4 \cdot 8$ & 18 & $78 \cdot 0$ \\
\hline & & $4 \cdot 8$ & 24 & $72 \cdot 7$ \\
\hline & & $4 \cdot 8$ & 28 & $68 \cdot 5$ \\
\hline & & $4 \cdot 8$ & 38 & $60 \cdot 4$ \\
\hline
\end{tabular}

The action of the killer factor was investigated under different $\mathrm{pH}$ and temperature conditions. Sensitive cells were added to samples of killer and control solutions. The cells were plated on media buffered at $\mathrm{pH} 4.8$ and/or 5.8 and incubated at $18^{\circ}, 22^{\circ} 24^{\circ}$ $28^{\circ}$ or $38^{\circ}$. The $\%$ of sensitive cells killed was estimated by comparing the number of colonies arising on killer and control plates. 
The results (Table 6) show that the post-absorption action of the killer depended on the growth conditions, and was not necessarily fatal unless the organisms were exposed to the optium conditions for the stability of the killer factor. It is interesting to note that the effect of temperature on the post-absorption action of the killer factor, contrasts with that on the action of megacin where post-adsorption death was proportional to the incubation temperature (Holland, 1962).

Treated sensitive yeast cells kept at $0^{\circ}$ for $0-72 \mathrm{hr}$ on agar plates buffered at $\mathrm{pH} 4.8$ did not subsequently recover when the cells were allowed to grow at $22^{\circ}$ (Woods, 1966).

Preliminary experiments indicated that the action of the killer factor was not reversed by exposing treated cells to papain. Further, washing and shaking treated cells did not affect the post-absorption action of the killer factor. This contrasts with the action of colicins, which is reversed by trypsin, suggesting that they are adsorbed on the cell surface (Nomura, 1964).

\section{DISCUSSION}

The killer factor in yeast, Saccharomyces cerevisiae, may be compared with any other agents involving killing and heredity, but the analogy between the killer factor and bacteriocins is particularly striking. Both act on strains of the same or closely related species and are proteinaceous in nature. The production and stability of the killer factor and some bacteriocins is very dependent on growth conditions, which must be carefully controlled for optimal titres. The killer factor is markedly more stable in agar medium than in broth. Similarly, many colicinogenic strains which produce good zones of inhibition on agar may show little or no activity in broth (Reeves, 1965).

The proteinaceous nature of the purified killer factor is indicated by its inactivation by papain, its absorption at 260 and $280 \mathrm{~m} \mu$, and the Folin-Ciocalteu test (1927) for proteins described here. The presence of aromatic moieties in the killer factor is suggested by both the significant absorption observed at $280 \mathrm{~m} \mu$ (Layne, 1957) and the adsorption of the factor by Sephadex. It is well known that Sephadex adsorbs predominantly aromatic and heterocyclic compounds (Gelotte, I960).

The size of the killer factor is at present unknown but the dialysis experiments suggest that it is a macromolecular protein.

The bactericidal action of the killer factor and that of megacin are very similar in many respects. First, growth of the treated sensitive organisms is required before death occurs. Secondly, the physiological state of the sensitive cells affects the amount of killing, and, thirdly, absorption and death of the organisms are separated into two distinct processes. Holland (1962) reported that the decrease in sensitivity, with age, of Bacillus megaterium strains to megacin is concurrent with the progressive development of an extensive slime layer. He suggested that the slime layer prevented or retarded the penetration of megacin to those structures where it exerted its lethal activity. At present the reason for the increased sensitivity of the sensitive yeast cells to the action of the killer factor during log phase is not known.

The post-absorption action of both the killer factor and megacin is affected by the growth conditions. The former requires that the organisms be exposed to the optimum conditions for the stability of the killer factor during growth, but the latter is not necessarily fatal unless the organisms are exposed to optimum growth conditions. Holland (1962) suggested the possible involvement of an enzymic system since the postabsorption death rate is proportional to the incubation temperature, and the 
$\mathrm{Q}_{10}\left(27-37^{\circ}\right)$ for the loss of viability is close to 2 . The effect of temperature between $28^{\circ}$ and $38^{\circ}$ on the action of the killer factor has the opposite effect resulting in a decrease in the \% killing.

Another example of the effect of the physiological state of the sensitive and temperature organisms on the activity of the bacteriocin, pesticin, produced by Pasteurella pseudotuberculosis was reported by Ben-Gurion \& Hertman (1958). They indicated that the activity of pesticin is 20 times greater when tested at $37^{\circ}$ than at $30^{\circ}$. However, it should be noted that the sensitive organism $P$. pseudotuberculosis grows more abundantly at $37^{\circ}$ than at $30^{\circ}$.

The authors wish to thank Mr J. Kirkham, who carried out the electron microscopy, and the Science Research Council for financial support of this work. One of us (D. R. W.) wishes to acknowledge a Rhodes Scholarship.

\section{REFERENCES}

Adams, M. H. (1948). Surface inactivation of bacterialviruses and of proteins. J. gen. Physiol. 3r, 417. ANDREWs, P. (1965). The gel filtration behaviour of proteins related to their molecular weights over a wide range. Biochem. J. 9r, 222.

Ben-Gurion, R. \& Hertman, I. (1958). Bacteriocin-like material produced by Pasteurella pestis. J. gen Microbiol. 19, 289.

Bevan, E. A. (1955). Investigations on the genetics of yeast (Saccharomyces cerevisiae). Ph.D. thesis, Glasgow University.

Bevan, E. A. \& Makower, M., (1963). The physiological basis of the killer character in yeast. Proc. IIth int. Congr. Genet. 1, 203 (abstract).

EgGsteIn, M. \& KreUTZ, F. H. (1955). Vergleichende Untersuchungen zur quantitativen Eiweissbestimmung in Liquor und eiweissarmen Lösungen. Klin. Wschr. 33, 879.

Folin, O. \& CrocalteU, V. (1927). On tyrosine and tryptophane determinations in proteins. J. biol. Chem. 73, 627.

GelotTE, B. J. (1960). Studies on gel filtration: sorption properties of the bed material Sephadex. J. Chromat. 3, 330.

Gomori, G. (1959). Preparation of buffers for use in enzyme studies. Meth. Enzymol. x, I38.

Granath, K. A. \& Flodin, P. (196I). Fractionation of dextran by the gel filtration method. Makromolek. Chem. 48, 160.

Hofsten, B. \& FAlKBring, S. (1960). A simple arrangement for the concentration of protein solutions. Analyt. Biochem. I, 436.

Holland, I. B. (1962). Further observations of the properties of megacin, a bacteriocin formed by Bacillus megaterium. J. gen. Microbiol. 29, 603.

JACOB, F. \& Wollman, E. (1959). Colicins and other bacteriocins. In Bacteriophages. Ed. by M. H. Adams. New York: Interscience Publishers Inc.

Kavanagh. (1963) Analytical Microbiology. New York: Academic Press Inc.

Kimmel, J. R. \& Sмгтн, E. L. (1954). Crystalline papain. I. Preparation, specificity and activation. J. biol. Chem. 207, $5 \mathrm{I} 5$.

LAYNE, E. (1957). Spectrophotometric and turbidimetric methods for measuring proteins. Meth. Enzymol. 3, 447.

Lederberg, J. \& Lederberg, E. M. (1952). Replica plating and the indirect selection of bacterial mutants. J. Bact. 63, 399.

Lindegren, C. (1949). The Yeast Cell: Its Genetics and Cytology. Saint Louis, U.S.A.: Educational Publishers Inc.

Lowry, B. H., Rosebrough, N. J., Farr, A. L. \& Randall, J. (I95I). Protein measurement with the Folin phenol reagent. J. biol. Chem. I93, 265.

MAKOWER, M. (1964). Inheritance of a killer reaction in yeast D.Phil. thesis. Oxford University. Nomura, M. (1964). Mechanism of action of colicins. Proc. natn. Acad. Sci. U.S.A. 52, I5I4. 
REAUME, S. E. \& TATUM, E. L. (1949). Spontaneous and nitrogen mustard induced nutritional deficiencies in Saccharomyces cerevisiae. Arch. Biochem. 22, 331.

ReEves, P. (1965). The Bacteriocins. Bact. Rev. $29,24$.

Topley and Wilson's Principles of Bacteriology and Immunity (1964). 5th Ed., revised by G. S. Wilson and A. A. Miles. London: Edward Arnold (Publishers) Limited.

Weime, R. J. (1965). Agar Gel Electrophoresis. Elsevier Publishing Company.

WILKINs, W. H. (1949). Investigation into the production of bacteriostatic substances by fungi. A revision of the testing method. Ann. appl. Biol. 36, 257.

Woods, D. R. (1966). Studies of the nature of the 'killer factor' in yeast. D.Phil. thesis. Oxford University. 